\title{
Effect of tube shelters on the growth of young Turkish pines (Pinus brutia Ten., Pinaceae)
}

\author{
Céline Leroy, Yves CARAGLIO* \\ UMR botAnique et bioinforMatique de l'Architecture des Plantes (AMAP), 2196 Bd. de la Lironde, TA40/PS2, \\ 34398 Montpellier Cedex 5, France
}

(Received 20 August 2002; accepted 24 February 2003)

\begin{abstract}
Young Turkish pine (Pinus brutia Ten.) individuals were planting, in the Montpellier region, with or without tube shelter alternating. The effect of these tubes was determinate thanks to the growth study of the main polycyclic stem (several elongation phases separated by rest periods). The analysis was done by a quantitative comparison of successive annual shoots and growth units on individuals of the same age, some with tube shelters and some without. The trees grown in tube shelters were taller, as a result of a larger number of growth units per annual shoot, and longer annual shoots and growth units. A more in-depth analysis revealed a difference in growth between 1997 growth units towards the bottom of the tube and those of 1998 towards the top. Generally speaking, the specific microclimate, inside the tube shelter, could modulate the growth expression of the Pinus brutia, Ten.
\end{abstract}

Pinus brutia / tube shelter / growth / polycyclism / environmental effect

Résumé - Influence du tube de protection sur la croissance de jeunes individus de pin de Brutie (Pinus brutia Ten., Pinaceae). De jeunes individus de pins de Brutie (Pinus brutia Ten.) ont été plantés, dans la région de Montpellier, en alternance avec et sans tube de protection. La répercussion de ce tube a été déterminée via l'étude de la croissance de l'axe principal polycyclique (plusieurs vagues d'allongement séparées par une phase de repos). Ainsi, l'analyse a été effectuée en comparant quantitativement les pousses annuelles successives et les unités de croissance d'individus de même âge. Les arbres situés dans les tubes de protection sont de plus grande taille et de plus petit diamètre. Cette plus forte croissance est le résultat d'un nombre plus élevé d'unités de croissance par pousse annuelle, de pousses annuelles et d'unités de croissance plus longues. Une analyse plus fine a permis de mettre en évidence une différence dans la croissance entre les unités de croissance de 1997 situées dans la partie basse du tube et les unités de croissance de 1998 situées dans la partie haute. D'une manière générale, le microclimat spécifique, à l'intérieur du tube de protection, aurait un effet modulateur sur l'expression de la croissance du pin de Brutie.

Pinus brutia / tube de protection / croissance / polycyclisme / influence du milieu

\section{INTRODUCTION}

A few years ago, foresters guarded against planting failures by using very high planting densities. This resulted in impenetrable stands and made the first thinned wood difficult to sell. Lower planting densities produce trees with thicker trunks by the time of the first thinning. But these lower densities are more subject to the animal attacks. In this way, at the end of the 1970s, Graham Tuley, a British researcher, designed an individual protective sheath against animal damage: the tube shelter or protective tube [30]. These tube shelters are use either in forest plantations or in agroforestry systems.

These polypropylene tubes, of different shapes and colours, improve striking rates, facilitate weeding, cut upkeep costs and stimulate and accelerate plant growth [23].

Various studies for the past ten years or so on different species in various climates as in France or in England have shown that tube shelters indeed have an impact on tree growth $[4,14$ 16, 26, 30]. According to Dupraz [14], however, their impact on vertical growth of hybrid Walnut trees (Juglans hindsii $\times$ Juglans regia), for instance, is temporary and that on diameter increment is negative. This type of reaction has also been observed in Prunus avium, Robinia sp., Sorbus domestica, Gleditschia sp. and Celtis australis [14]. The conifers are apparently even more affected by the reduction in diameter increment. Stone pine (Pinus pinea L.) stems are only half as thick after three years, but benefit from the positive effect on vertical growth. For the Cypress and Douglas fir, tube shelters penalize both vertical growth and diameter increment.

Our study set out to determine the impact of tube shelters on stem height and diameter. So as to break down the effects of tube shelters, we opted to study a species that has several

\footnotetext{
* Corresponding author: celine.leroy@ cirad.fr
} 
growth phases during a single growth season, separated by rest periods (polycyclism). The study of a polycyclic species allow us to decompose the lenght on further morphological entities. The species was Turkish pine ${ }^{1}$ (Pinus brutia Ten.), which belongs to halepensis section [1]. It is a strictly Mediterranean eastern species, found in eastern Greece, Turkey, Crete, Cyprus, Syria, Lebanon [2, 9, 31]. The effects of tube shelters on growth were determined using the number and the lenght of growth phases of the stem. So, we compared the growth of individuals in tube shelters with others left to grow freely. A reminder of the morphological structure of the species is given below, followed by the quantitative comparative analysis of stem growth.

\section{MATERIALS AND METHODS}

\subsection{The study site and the plant material}

The study was conducted in 1999 at the Domaine Départemental de Restinclières, Prades-Le-Lez, north of Montpellier, Hérault, France. The climate is Mediterranean, with an average of $750 \mathrm{~mm}$ of annual rain. The Turkish pines (Pinus brutia Ten.) studied were four years old from the germination in 1995 and were 1 year when they were planted on an area of around 5 ha, on a shallow, stony, chalky soil. The planting alternated one row of one-year seedling pines and five rows of vines. The pines were planted $2 \mathrm{~m}$ apart along the row, alternating trees with and without tube shelters. Two sorts of cylindrical beige tubes were used: $120 \mathrm{~cm}$ tall and $10 \mathrm{~cm}$ in diameter (small diameter), and 120 tall and $15 \mathrm{~cm}$ in diameter (large diameter). Fifty individuals without and 43 with shelters were studied. The difference between the 2 trees is due to the death of 7 individuals with shelter.

\subsection{Study protocol}

The sampling protocol was based on measuring annual growth by marking off the stem sections emitted.

\subsubsection{Morphological study}

In Turkish pine, the annual shoot (AS), which corresponds to the section of stem formed during a given growth season [6], comprises one or more growth units (GU). According to Hallé and Martin [21], a growth unit corresponds to the section of stem established during an uninterrupted elongation phase. The growth units of the genus Pinus, which are clearly structured with three main zones -a scale leaves zone, a brachyblastes (dwarf branches) zone and a tier of branches zone (Fig. 1A)- have been described by numerous authors $[5,7,8$, $10,11,22]$. The annual shoots of Turkish pines may have one, two, three, ... (Fig. 1A) or even six GU. These types of annual shoots are termed mono-, bi-, tri-, ... and hexacyclic respectively. Each first growth unit is named GU 1, each second growth unit GU 2 and so on (Fig. 2A).

The successive tiers of branches can easily distinguish the growth units. They correspond to the forester notion of "node" $[13,24,28]$ and to the notion of "morphogenetical" cycle $[5,6,24]$. The major difficulty in our study was to distinguish between the annual shoots. Branch structure and layout on the main stem were the main criteria to be used. The lateral buds emitted on the terminal part of the growth unit may develop immediately or after a certain delay. These last ones are borne by a pseudo-whorl (the internodes are very short) and have a broad point of insertion on the main stem and short internodes towards the base (Fig. 1B). These branches mark the winter stop in growth, and are known as inter-annual branches. As a result, a tier of delayed branches marks off an annual shoot. Conversely, the branches that develop immediately and which are located between two growth units within the annual shoot are known as intra-annual branches. There is a greater distance between them, and they have long internodes towards the base and a smaller diameter than delayed branches (Fig. 1C).

\subsubsection{Quantitative study}

In order to realise a quantitative analysis of growth [3, 17-19, 25], a morphological study is essential to recognise the different morphological entities, which are the growth units and the annual shoots.

For each individual, we measured the total height and basal diameter, length of 1997 and 1998 annual shoots, and the length of each growth unit during 1997 and 1998. The different measurements were then put into the Excel software (Microsoft), using a topological coding system [18]. This system, which respects the breaking up of the plant into different units, is the means of entry into the AMAPmod software, with a view to extracting and analysing data (http:// amap.cirad.fr/).

To analyse the actual impact of the tube shelter on growth unit length, we broke down the study of growth units by distinguishing between those inside and those outside the shelter (Fig. 2B). We then grouped the growth units according to their position on the annual shoot, irrespective of its polycyclism rate (cf. Fig. 2A).

The different means calculated were given with a confidence interval of $95 \%$. Their comparison was validated using the MannWhitney-Wilcoxon non-parametric test $[27,29]$, at the $95 \%$ threshold.

\section{RESULTS}

\subsection{Overall influence of tube shelters on the height and the diameter}

The individuals with shelters were significantly (1.5 times) higher than those without (Fig. 3), at $128.1 \mathrm{~cm} \pm 2.9 \mathrm{~cm}$ compared to $79.3 \mathrm{~cm} \pm 1.6 \mathrm{~cm}$ respectively. There was also a significant difference in basal diameter for the individuals with and without shelters (Fig. 3), with $1.8 \mathrm{~cm} \pm 0.12 \mathrm{~cm}$ and $1.4 \mathrm{~cm} \pm 0.08 \mathrm{~cm}$ respectively. However, we observed a greater spread of basal diameters for the individuals without shelters. The height to diameter ratio (H:D) was twice as high on average for the trees with shelters as for those without. There was no significant difference in overall tree height between the two types of shelter -small- and large-diameter-, with $128.7 \mathrm{~cm} \pm 8.9 \mathrm{~cm}$ and $127.5 \pm 8.7 \mathrm{~cm}$ respectively. Basal diameter was not affected by the difference in tube diameter.

At the end of 1996, the height of the trees was significantly different with $24 \mathrm{~cm} \pm 1.3 \mathrm{~cm}$ for the individuals without tubes and $28.5 \mathrm{~cm} \pm 2.5 \mathrm{~cm}$ for the ones in the tube shelters. 2 years after (end of 1998), the height was multiplied by 3.3 for the individuals without tubes and was multiplied by 4.5 for the trees with shelters.

${ }^{1}$ Also known as East Mediterranean pine or Calabrian pine. 


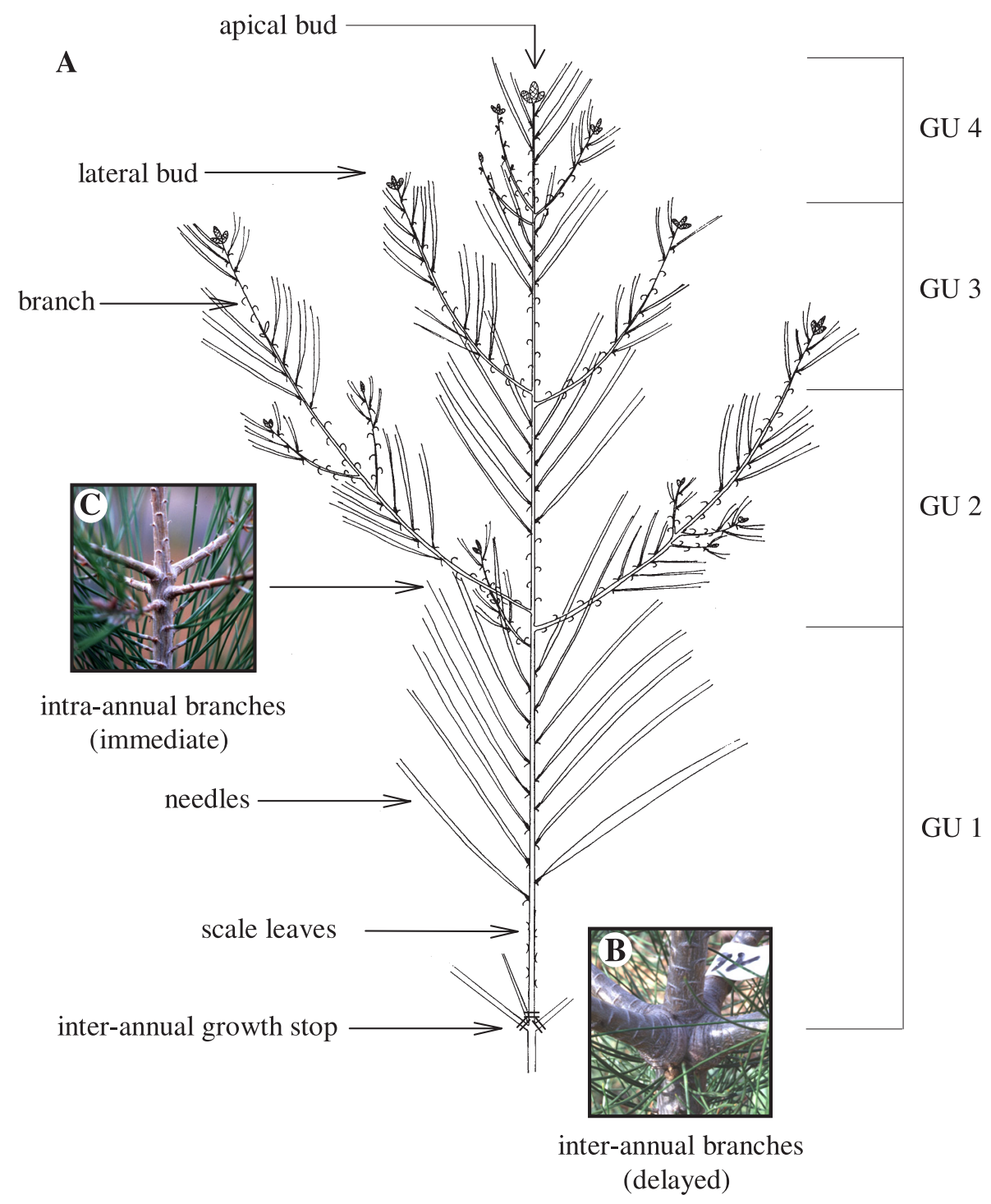

Figure 1. Diagram of a tetracyclic annual shoot (four growth units), with photos of inter-annual branches $(\mathbf{A})$ and intra-annual branches (B) (photos C. Leroy).

\subsection{Influence of the tube shelters on the annual shoot structure}

Average annual shoots length, all polycyclism categories combined, was significantly greater for the individuals with tube shelters than for those without, for both $1997(33.9 \mathrm{~cm} \pm$ $2.3 \mathrm{~cm}$ and $21.3 \mathrm{~cm} \pm 1.9 \mathrm{~cm})$ and $1998(62.7 \mathrm{~cm} \pm 3.0 \mathrm{~cm}$ and $36.1 \mathrm{~cm} \pm 3.6 \mathrm{~cm}$ ) (Fig. 4). Compared to 1997, 1998 was characterized by a significant increase in annual shoot length, for trees both with and without tube shelters (Fig. 4).

For both 1997 and 1998, the polycyclism rate was higher for individuals with tube shelters. For 1997 (Fig. 5A), the individuals without shelters had a majority of bi- and tricyclic annual shoots (two and three GU per AS), while those with shelters had a majority of tri- and tetracyclic annual shoots (three and four growth units per annual shoot). For 1998 (Fig. 5B), the individuals without shelters had a large majority of tricyclic annual shoots, and those with shelters had a high proportion of tetra- and pentacyclic annual shoots (four and five growth units per annual shoot) (Fig. 5).

According to the polycyclism rate (Fig. 6), the mean of the annual shoot length shows that there is an increase of the length for both 1997 and 1998 with or without a tube shelter.

The comparison for all polycyclism rate show that the 1998 annual shoots with a tube are significantly longer than the ones without a tube (Fig. 6B). Contrary to the 1997 annual shoots, there is only a significative difference for the bi- and pentacyclic annuals shoots between the ones with and without a tube (Fig. 6A). For the 1997 annual shoots with or without a tube there is only a significative difference between the bi- and tetracyclic and between the tri- and pentacyclic ones (Fig. 6A). On the other hand, for the 1998 annual shoot length there is a significative difference for the individuals with a tube shelter contrary to the ones without a tube (Fig. 6B). 
A

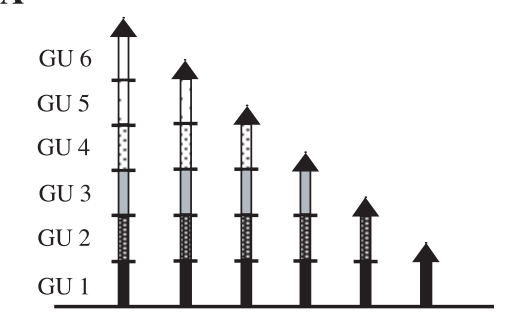

B

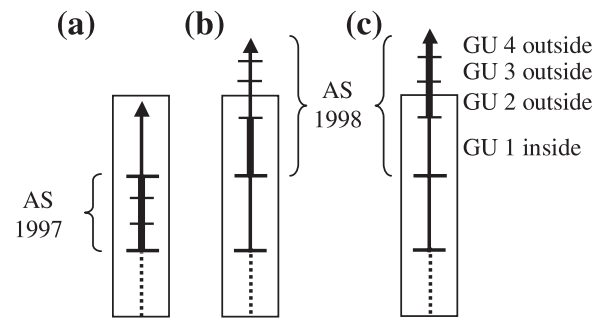

Figure 2. (A) Clustering of growth units according to their position on the annual shoot. (B). Position of growth units on 1997 and 1998 annual shoots, depending on whether they were inside the tube shelter (a) and (b) or outside (c). AS = annual shoot, GU = growth unit.

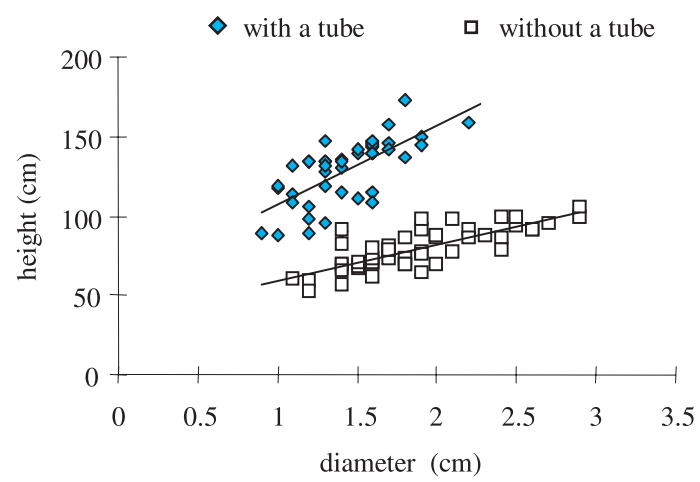

Figure 3. Total height in centimeters $(\mathrm{cm})$ according to the basal diameter in centimeters for 50 individuals without a tube shelter and 43 individuals with a tube shelter measured at the end of 1998 .

\subsection{Influence of the tube shelters on the growth unit length}

- Each annual shoot was decomposed in growth units. So, in respect to the test comparison hypothesis, we only consider the tri- and tetracyclic annual shoots which were enough numerous $(>8)$. The average length was greater on individuals with tube shelters than on those without (Fig. 7). In most cases, the first growth unit was much longer than subsequent growth units. There was no significant difference in growth unit length for the 1997 tetracyclic annual shoots on trees with a tube shelter (Fig. 7C). For the others, tricyclic 1997, 1998 and tetracyclic 1998 there is a significant difference of their length. There is a gradual reduction in mean length for the successive growth units within an annual shoot (Fig. 7).

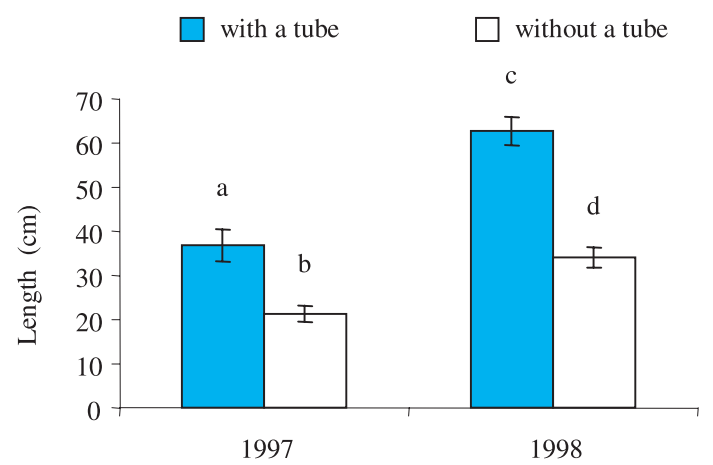

Figure 4. Comparison of the mean total length of annual shoots in centimeters $(\mathrm{cm})$ with the confidence interval between 43 individuals with a tube shelter and 50 individuals without a tube shelter. a, b, c and d: Comparison using the Mann-Whitney-Wilcoxon test; in the event of a change of letter between two bars on the chart, the difference is significant at the $95 \%$ threshold.

- Now, we consider all the growth units according to their rank (GU 1, GU 2, ..., Fig. 2B). Some 1998 annual shoots were entirely inside the tubes, some a part inside and a part outside (these ones are considered as outside), and some totally outside. There is a significant difference of the successive length for the 1997 growth units without a tube and for the 1998 growth units with and without a tube shelter (Figs. 8A, 8B, 8D and 8E). The 1997 growth units inside the tube (Fig. 8C) have no significative difference between GU 2, GU 3 and GU4. The lengths of these 3 last ones are significantly different with the GU 1. Contrary to 1997 growth units inside the tube shelter, the average length of the successive 1997 growth units without a tube and the 1998 growth units entirely inside or outside the tubes (Figs. 8D and 8E) decreased according to their rank (GU 1, GU 2, ..).

The statistical comparison of the 1997 growth units length for the trees without a tube shelters (Fig. 8A and Tab. I) are significantly shorter than the ones for the trees with a tube shelter. There is no significative difference of the length between the first 1997 growth units without a tube and the same ones inside the tube (Figs. 8A, 8C and Tab. Ia). In the same way, the 1998 growth units length for the trees without the tube (Fig. 8B) are significantly shorter than the ones inside the tube (Figs. 8B, 8D and Tab. Ib). The same comparison has been done between the 1998 growth units without the tube and the 1998 growth units outside the tube (Figs. 8B, 8E and Tab. Ic).

\section{DISCUSSION}

Generally speaking, tube shelters had a positive effect on Turkish pine height and diameter. The H:D ratio was strongly affected. The individuals with tube shelters had a more slender growth habit than those without.

These results go in the same way of these on the Pinus pinea [14] with positive effect on vertical growth and negative effect on the diameter increment. According to study made by Dupraz [14] on Prunus avium, Sorbus domestica, Gleditschia sp. 
A

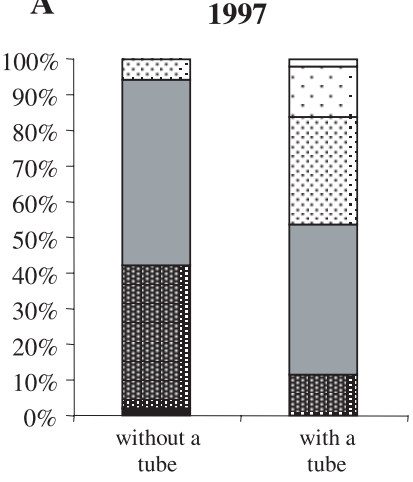

B

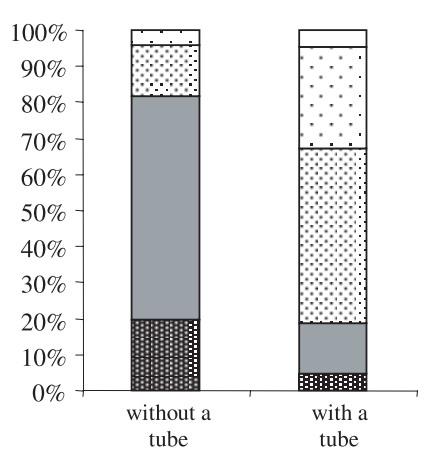

Figure 5. Frequency (in percent) of the number of growth units per annual shoot (polycyclism rate) for 43 individuals with a tube shelter and 50 individuals without a tube shelter, for the years 1997 (A) and 1998 (B). GU = growth unit.
A

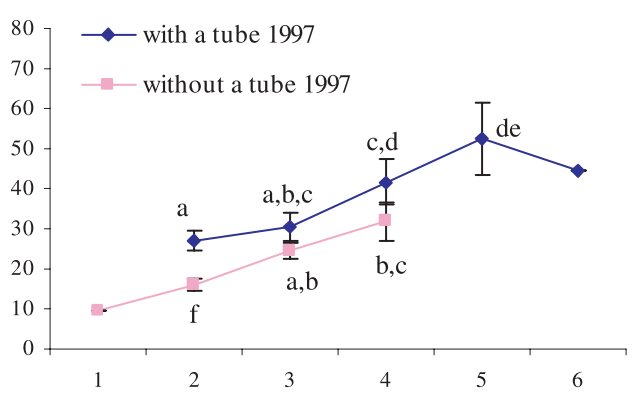

B

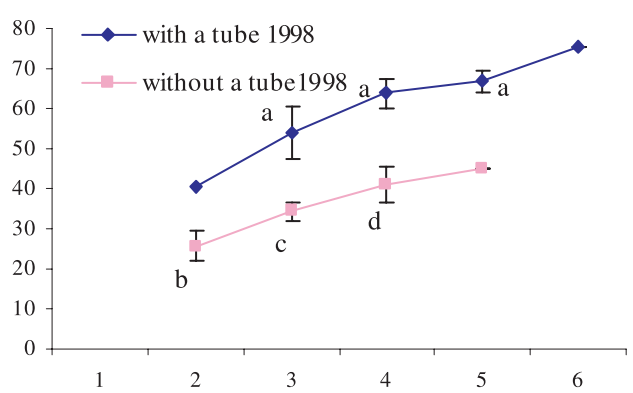

Figure 6. Mean length of annual shoots in centimetres $(\mathrm{cm})$ and their confidence interval according to the polycyclism rate for individuals with and without a tube shelter. a, b, c, $\mathbf{d}, \mathbf{e}$ and $\mathbf{f}$ : Comparison using the MannWhitney-Wilcoxon test; in the event of a same letter between two points on the chart, the length difference non significant at the $95 \%$ threshold.

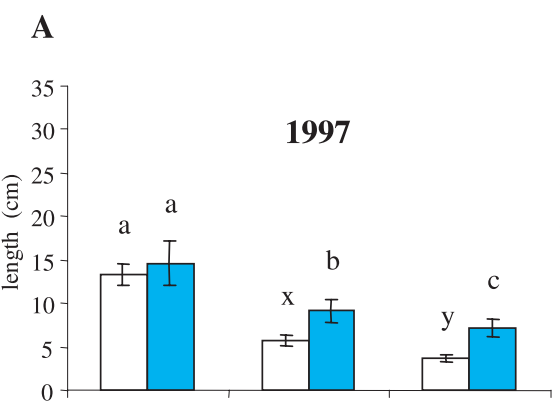

GU 1

\section{C}

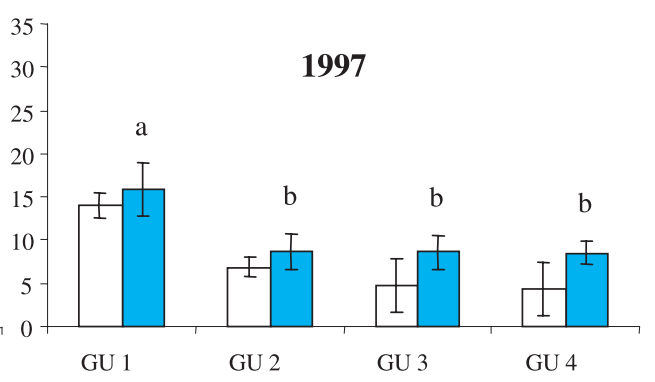

Tetracyclic AS

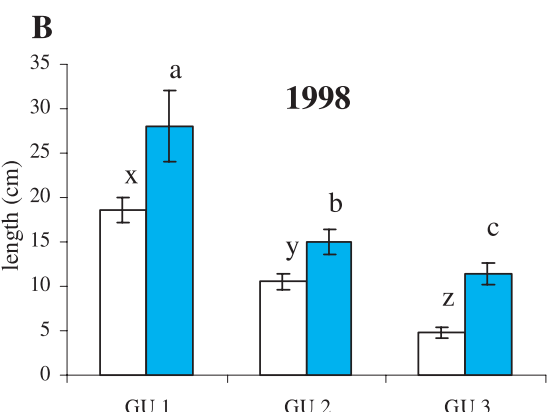

GU 1
GU 2

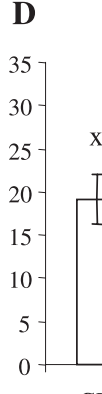

1998 b b

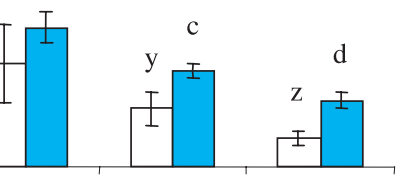

Figure 7. Mean length of growth units in centimetres $(\mathrm{cm})$ and their confidence interval for tricyclic annual shoots, with 26 individuals without a tube shelter and 18 individuals with a tube shelter for 1997 (A) and 31 individuals without a tube shelter and 6 individuals with a tube shelter for 1998 (B). The 1997 tetracyclic annual shoots $(\mathbf{C})$ are represented by 3 individuals without a tube shelter and 13 individuals with a tube shelter and those for 1998 (D) by 7 individuals without a tube shelter and 21 with a tube shelter. a, $\mathbf{b}, \mathbf{c}, \mathbf{x}, \mathbf{y}$ and $\mathbf{z}$ : Comparison using the Mann-Whitney-Wilcoxon test; in the event of a change of letter between two bars on the chart, the length difference is significant at the $95 \%$ threshold. The three successive growth units on tricyclic annual shoots are designated GU 1, GU 2 and GU 3 respectively and likewise for tetracyclic annual shoots. 

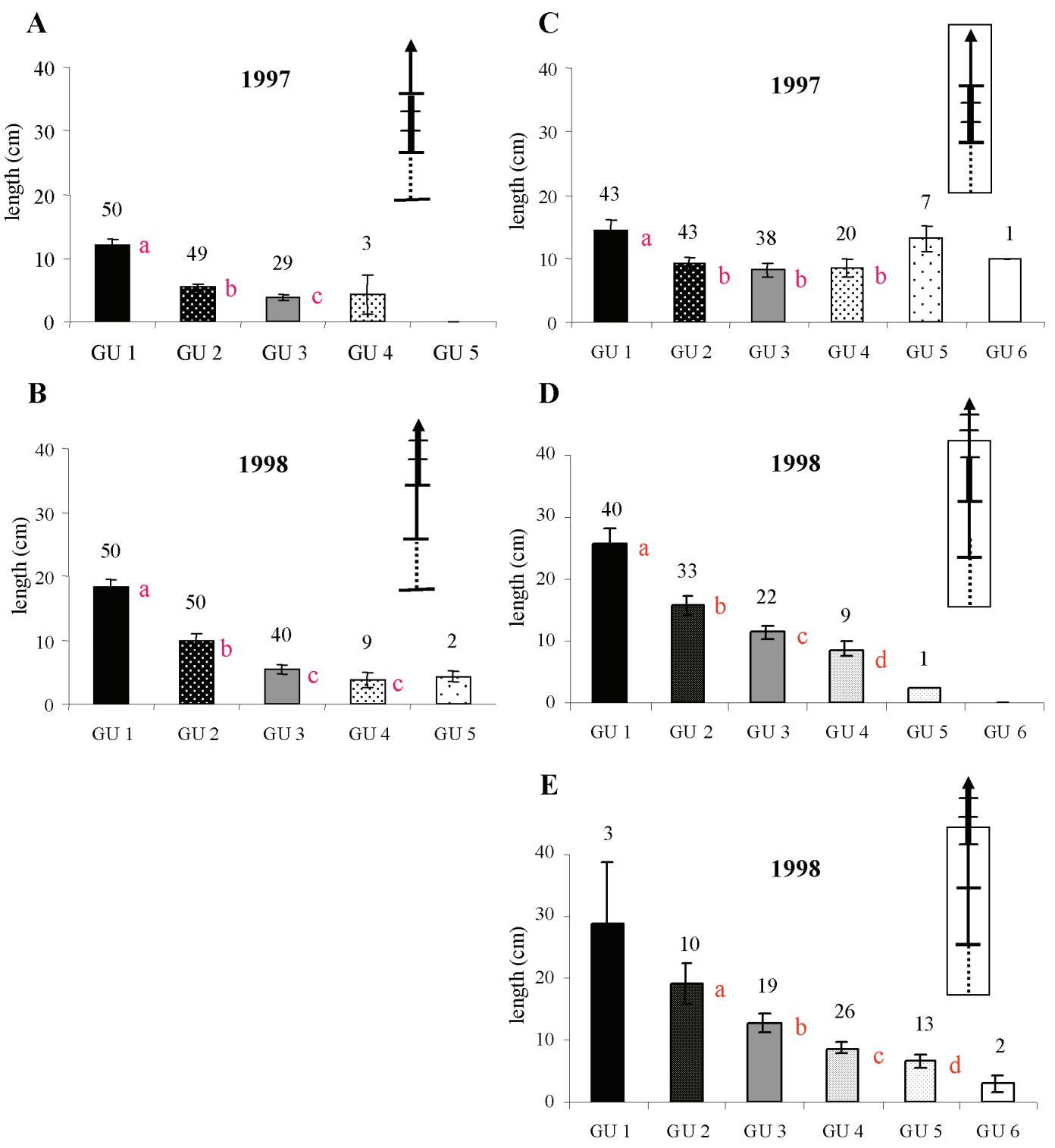

Figure 8. Mean length in centimetres $(\mathrm{cm})$ and their confidence intervals of growth units according to their position on the annual shoots, irrespective of polycyclism rate, for individuals without a tube shelters for the 1997 (A) and 1998 (B). Mean length in centimetres (cm) of growth units according to their position on the annual shoots, irrespective of polycyclism rate, for individuals with a tube shelter for 1997 inside the tube (C), for 1998 inside the tube (D) and for 1998 outside the tube $(\mathbf{E})$. a, b, c and d: Comparison using the Mann-Whitney-Wilcoxon test; in the event of a change of letter between two bars on the chart, the difference is significant at the $95 \%$ threshold. GU = growth unit, the numbers quoted above each bar of the chart correspond to the numbers concerned.

and Celtis australis, vertical growth is considerably stimulated but the effect disappears after eight years, and diameter increment is reduced, an effect that persists.

However, for the Cypress and the Douglas tube shelters penalize both vertical growth and diameter increment [14]. The tube shelters allow the oak trees (Quercus petraea and Quercus robur) a better primary growth and in the same way a stronger radial increment than the ones without tubes [30]. Shelters allow oak trees to be established quickly with a short length of straight stem but once outside the tube oak reverts to its normal bushy growth habit.
Thank to the primary growth decomposition, in annual shoots and growth units, different growth characteristics can be underlined between the individuals with and without tube shelters. The individuals in the tubes express longer annual shoots and growth units and a higher polycyclism rate than the ones without the tubes. So, according to our results, the greater height of trees grown in tube shelters is the result to both longer growth units and a greater number of growth units per year. For Guérard [20], in the case of the red oak (Quercus rubra L.), the control of the herbaceous competition generates an increase of different parameters concerning tree architecture 
Table I. Comparison using the Mann-Whitney-Wilcoxon test to compare the growth units (GU) length (a) between the 1997 ones without a tube A/GU1, A/GU2, ... (see Fig. 8A) and the 1997 ones with a tube C/GU1, C/GU2, ... (see Fig. 8C). (b) Between the 1998 ones without a tube B/GU1, B/GU2, ... (see Fig. 8B) and the 1998 ones inside the tube D/GU1, D/GU2, ... (see Fig. 8D). (c) And between the ones without a tube B/GU1, B/GU2, ... (see Fig. 8B) and the ones outside a tube E/GU1, E/GU2, ... (see Fig. 8E). ns = no significative difference tested with the Mann-Whitney-Wilcoxon non parametric test at the $95 \%$ threshold, $* *$ : significative difference tested with the Mann-Whitney-Wilcoxon non parametric test at the 95\% threshold, -: the Mann-Whitney-Wilcoxon non parametric test is not possible because there is not enough individuals.

\begin{tabular}{lccccc}
\hline (a) & C/GU 1 & C/GU 2 & C/GU 3 & C/GU 4 & C/GU 5 \\
\hline A/GU 1 & $\mathrm{ns}$ & $* *$ & $* *$ & $* *$ & $\mathrm{~ns}$ \\
$\mathrm{~A} /$ GU 2 & $* *$ & $* *$ & $* *$ & $* *$ & $* *$ \\
$\mathrm{~A} /$ GU 3 & $* *$ & $* *$ & $* *$ & $* *$ & $* *$ \\
$\mathrm{~A} /$ GU 4 & - & - & - & - & -
\end{tabular}

\begin{tabular}{lccccc}
\hline (b) & D/GU 1 & D/GU 2 & D/GU 3 & D/GU 4 & D/GU 5 \\
\hline B/GU 1 & $* *$ & $\mathrm{~ns}$ & $* *$ & $* *$ & - \\
$\mathrm{B} / \mathrm{GU} 2$ & $* *$ & $* *$ & $\mathrm{~ns}$ & $* *$ & - \\
$\mathrm{B} / \mathrm{GU} 33$ & $* *$ & $* *$ & $* *$ & $* *$ & - \\
$\mathrm{B} / \mathrm{GU} 4$ & $* *$ & $* *$ & $* *$ & $* *$ & - \\
\hline (c) & $\mathrm{E} / \mathrm{GU} 1$ & $\mathrm{E} / \mathrm{GU} 2$ & $\mathrm{E} / \mathrm{GU} 3$ & $\mathrm{E} / \mathrm{GU} 4$ & $\mathrm{E} / \mathrm{GU} 5$ \\
\hline $\mathrm{B} / \mathrm{GU} 1$ & -- & $\mathrm{ns}$ & $* *$ & $* *$ & - \\
$\mathrm{B} / \mathrm{GU} 2$ & $* *$ & $* *$ & $\mathrm{~ns}$ & $* *$ & - \\
$\mathrm{B} / \mathrm{GU} 3$ & $* *$ & $* *$ & $* *$ & $* *$ & - \\
$\mathrm{B} / \mathrm{GU} 4$ & $* *$ & $* *$ & $* *$ & $* *$ & - \\
\hline
\end{tabular}

(i.e. the rate of polycyclism). In our case, the tube shelter could be seen as playing the same role and maybe affect the hydric growth condition of the tree.

In order to better understand the different behaviours of the trees, different authors were interested in the air composition inside the tube $[4,12,14,16,26]$. There is a specific microclimate inside the shelters, which differs from the outside climate in four major ways [14]: greater air temperature variations, a qualitative and quantitative modification of the light transmitted through the tube wall, the permanently very high relative humidity of the air, and its very low carbon dioxide content. The limiting factor due to the tube is the low degree of $\mathrm{CO}_{2}$ renewal inside it [15]. However, the tube shelters used to protect Turkish pines at the Domaine de Restinclières have five small openings at their base. According to Dupraz [15], these ventilation holes have to be of a very specific size to enable a "chimney effect", i.e. hot, moist air rises up the tube and cool, dry, $\mathrm{CO}_{2}$-rich air is drawn in. This flow of air prevents the decrease in tree photosynthetic activity due to a lack of $\mathrm{CO}_{2}$ [15].

There is a real difference on annual shoot length between the two years, 1997 and 1998, especially due to the polycyclism rate for the tree with or without the tube shelter. A non significative difference on annual shoot length for 1997 can be explained by the tree establishment phase where the growth is not much modulated by the environment. Whereas, the fact that for 1998 annual shoots inside the tube are longer than the one outside could indicate a bigger effect of the tube shelter on tree growth this year.

Distinguished between the growth units inside and outside the tube shelters enabled to observe two different situations on growth unit length according to the position of the growth unit in the tube. Firstly, the 1997 growth units inside the tube don't show a significative difference on their length (Fig. 8C) like the 1997 growth units of the trees without the tube (Fig. 8A). Secondly, the 1998 growth units in the top of the tube (Fig. 8D), have developed in a similar way to those outside the tube (Fig. 8E), like the ones of 1998 for the trees without the tube shelter (Fig. 8B).

The endogenous expression of the Pinus brutia growth is to show a decrease of the growth unit length along the annual shoot. This phenomenon is observed for all the annual shoots except for the 1997 annual shoots inside the tube shelter (Fig. 8C).

Tree primary growth is the result of two mechanisms: organogenesis and growth unit extension. The tube shelter can play a part at the organogenesis level in making variations on the mitotic activity from the apex to initiate new metamers [6]. By increasing photosynthetic activity, more growth units could be produced for the individuals with a tube shelter.

The different results on the primary growth of Pinus brutia indicated that the variations in environmental conditions caused by the tube shelter do not actually modify the architecture of the trees, but merely modulate the expression of their annual shoot structure.

\section{CONCLUSION}

The different results obtained from the quantitative analysis of the main stem of young Turkish pines demonstrated that the tube shelters had a real effect on Turkish pine height and diameter compared to those without a tube shelter. The greater vertical growth of individuals grown in tube shelters results from an increase in growth unit length, and to a higher polycyclism rate of annual shoots. These results could be related to the micro-environmental conditions inside tube shelters.

So as to understand the gradient inside the tube shelter better, it would be worth sampling needles all the way up the tube and observe whether their width and the number of stomata change. In this way, the number of needles could allow us to have an idea of the organogenesis and the leaf biomass allocation and with the leaf area to have an idea of the assimilation rate. This could contribute to understand how the tube shelters modify the physiological parameters of the stem growth.

Moreover, the different measurements should be continued to determine whether the effect on growth of tube shelters persists. This would show whether the duration of the effect of such shelters is limited as demonstrated for certain species [14, $15,30]$, and could therefore be used to accelerate growth of Turkish pines, for instance to enable young trees to grow more quickly and thus avoid the strong competition they face from dense natural vegetation. 
Acknowledgements: This work was conducted under the PIRAT project: "Programme Intégré de Recherches en Agroforesterie à Restinclières", which involves around a dozen research teams. The authors would like to thank Christian Dupraz, who enabled this work by making Turkish pine plantings available to us, along with the Domaine de Restinclières management team. We also thank $\mathrm{H}$. Burford for the translation of the paper.

\section{REFERENCES}

[1] Barbéro M., Loisel R., Quézel P., Richardson M., Romane F., Pines of the Mediterranean Basin, in: Richardson D.M. (Ed.), Ecology and Biogeography of Pinus, Cambridge Univerity Press, 1998, pp. $153-170$.

[2] Bariteau M., Variabilité géographique et adaptation aux contraintes du milieu méditerranéen des pins de la section halepensis : résultats (provisoires) d'un essai en plantations comparatives en France, Ann. Sci. For. 49 (1992) 261-276.

[3] Barthélémy D., Caraglio Y., Modélisation et simulation de l'architecture des arbres, Bulletin de la vulgarisation forestière, Forêt Entreprise 73 (1991) 28-39.

[4] Bergez J.E., Influence des protections individuelles à effet de serre sur la croissance de jeunes arbres, Thèse de Doctorat, Université Montpellier II, 1993, 159 p.

[5] Bugnon P., Bugnon F., Feuilles juvéniles et pousses multinodales chez le pin maritime, Bull. Soc. Hist. Nat. de Toulouse, $n^{\circ} 86,1951$, pp. 18-23.

[6] Caraglio Y., Barthélémy D., Revue critique des termes relatifs à la croissance et à la ramification des tiges des végétaux vasculaires, in: Bouchon J., de Reffye P., Barthélémy D. (Eds.), Modélisation et simulation de l'architecture des végétaux, Science Update, INRA, Versailles, 74, 1997, pp. 11-87.

[7] Debazac E.F., Notes sur les différentes évolutions des points végétatifs chez les Pins et plus spécialement chez Pinus sylvestris L., Bull. Soc. Bot. de France 109 (1961) 114-119.

[8] Debazac E.F., Morphologie et sexualité chez les pins, Rev. For. Fr. 4 (1963) 293-303.

[9] Debazac E.F., Manuel des conifères, 1964, 172 p.

[10] Debazac E.F., La morphogenèse chez les Pinacées et ses rapports avec les caractères biologiques des espèces et la classification, Mém. Soc. Bot. Fr. 114 (1966) 72-83.

[11] Debazac E.F., Les modalités de la croissance en longueur chez les Pins, Bull. Soc. Bot. de France (1966) 3-14.

[12] Dias A.S., Tavares P., Nunes J., Silva A.M., Pereira J.S., Condiçoes microclimàticas em abrigos individuais usados na protecçao de sobreiros jovens, II Congresso Florestal Nacional, 1990, Porto, Portugal.

[13] Doak C.C., Evolution of foliar types, dwarf shoots, and cone scales of Pinus, Ill. Biol. Monogr. 13 (1935) 1-106.
[14] Dupraz C., Les protections de plants à effet de serre, Première partie : ce qu'en pensent les arbres... Rev. For. Fr. 49 (1997) 417 432.

[15] Dupraz C., Les protections de plants à effet de serre. Deuxième partie : amélioration de leur efficacité par aération optimisée et luminosité accrue, Rev. For. Fr. 49 (1997) 519-530.

[16] Dupraz C., Bergez J.E., Carbon dioxide limitation of photosynthesis of Prunus avium L., seedlings inside an unventilated tree shelter, For. Ecol. Manage. 100 (1998) 1-9.

[17] Godin C., Costes E., Caraglio Y., Exploring plant topological structure with the AMAPmod software: an outline, Silva Fenn. 31 (1997) 357-368.

[18] Godin C., Guedon Y., Costes E., Caraglio Y., Measuring and analysing plants with the AMAPmod software, in: CSIRO (Ed.), Plants to ecosystems: advances in computational life sciences, Australia, 1997, pp. 53-84.

[19] Godin C., Caraglio Y., A multiscale model of plant topological structures, J. Theor. Biol. 191 (1998) 1-46.

[20] Guérard N., Barthélémy D., Cabanettes A., Courdier F., Trichet P., Willm J., Influence de la compétition herbacée sur la croissance et l'architecture de jeunes Chênes rouges d'Amérique (Quercus rubra L.) en plantation, Ann. For. Sci. 58 (2001) 395-410.

[21] Hallé F., Martin R., Étude de la croissance rythmique chez Hevea brasiliensis Müll. Arg. (Euphorbiaceae-Crotonoïdeae), Adansonia, série 2, 8 (1968) 475-503.

[22] Kremer A., Décomposition de la croissance en hauteur du pin maritime (Pinus pinaster Aït.) : architecture génétique et application à la sélection précoce, Thèse de Doctorat, Université de Paris XI, 1992, $124 \mathrm{p}$.

[23] Pilard-Landeau B., Bilan des essais sur les tubes-abris à effet de serre installés par l'ONF, ONF-Bulletin technique $n^{\circ} 39,2000$, pp. 19-31.

[24] Prat H., Sur la correspondance entre la structure des pousses de pins et les cycles saisonniers, in: Livre Jubilaire dédié au prof, Lucien DANIEL, Oberthur, Rennes, 1936, pp. 1-19.

[25] Reffye de P., Houllier F., Blaise F., Barthélémy D., Dauzat J., Auclair D., Modélisation et simulation de la croissance d'une architecture végétale : approche morphologique expérimentale, in Blasco F., Tendances nouvelles en modélisation pour l'environnement, Paris, 1996, pp. 91-112.

[26] Rendle E.L., The influence of tube shelters on microclimate and the growth of oak, Proceeding of 6th meeting of National Hardwoods Programme, Oxford Forestry Institute, 1985, pp. 8-16.

[27] Saporta G., Probabilités, analyse des données et statistique, Technip (Ed.), Paris, 1990, 493 p.

[28] Shaw G.R., Characters of Pinus: the lateral cone, Botanical Gazette 43 (1907) 205-209.

[29] Snedecor G.W., Cochran W.G., Statistical methods, 8th ed., IOWA State University Press/AMES, 1989, 503 p.

[30] Tuley G., The growth of young oak trees in shelters, Forestry 58 (1985) 181-195.

[31] Vidakovi M., Conifers morphology and variation, 1991, 754 p. 